\title{
Beyond Aid: How Much Should African Countries Pay to Borrow?
}

Cheikh A. Gueye and Amadou N. R. Sy 


\title{
IMF Working Paper
}

\section{African Department and IMF Institute}

\section{Beyond Aid: How Much Should African Countries Pay to Borrow? \\ Prepared by Cheikh A. Gueye and Amadou N. R. Sy}

Authorized for distribution by John Wakeman-Linn and Marc Quintyn

June 2010

\begin{abstract}
This Working Paper should not be reported as representing the views of the IMF. The views expressed in this Working Paper are those of the author(s) and do not necessarily represent those of the IMF or IMF policy. Working Papers describe research in progress by the author(s) and are published to elicit comments and to further debate.

Post debt relief, the number of African countries considering accessing international capital markets, often to fund large infrastructure projects, is increasing. Potential risks of capital inflows are well known but the literature offers little help to estimate the cost of borrowing internationally for the first time. This paper proposes a two-step approach to estimate the sovereign credit rating and interest rate cost of a country considering borrowing externally. Estimates can be used to assess the costs and benefits of different financing options. The method can also be used to construct foreign currency as well as domestic local currency yield curves.
\end{abstract}

JEL Classification Numbers:F3, F34, G24

Keywords: Credit Ratings, Debt, First-Time Issuers, Push and Pull Factors, Sovereign Bonds, Spreads, Sub-Saharan Africa

Author’s E-Mail Address:cgueye2@imf.org; asy@imf.org

\footnotetext{
${ }^{1}$ The authors would like to thank Rabah Arezki, and Fabio Comelli for helpful comments and suggestions, and Ning $\mathrm{Fu}$, and Ermal Hittaj for assistance with the data.
} 


\section{Contents}

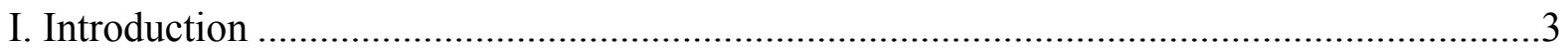

II. Simple "Pull” and "Push" Models of Capital Markets Inflows .........................................5

A. A Simple Macro Model of "Push" and "Pull" Factors ............................................

B. A Simple Finance Model of "Push" and "Pull" Factors ........................................6

III. Using Sovereign Credit Ratings to Proxy for "Pull” Factors ...........................................7

Table 1. Sovereign Rating Scale ...............................................................9

Table 2. Estimation Results ......................................................................... 10

IV. Estimating Sovereign Bond Yield Spreads using "Push" and "Pull" Factors ..................10

Table 3. Estimating Emerging Market Bond Spreads 2000-2009 ................12

Table 4. Liquidity and Emerging Market Bond Spreads 2000-2009 ..............14

Table 5. Actual and Estimated Sovereign Credit Ratings, Spreads, and Interest

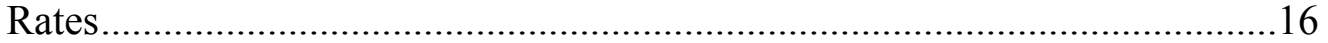

V. Constructing Sovereign and Corporate Yield Curves................................................17

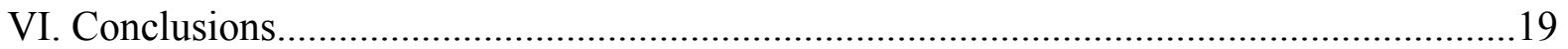

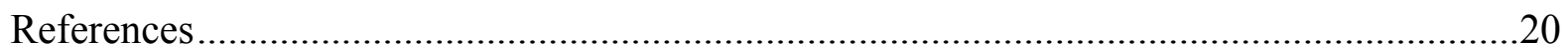




\section{INTRODUCTION}

Most low income countries (LICs) in Africa have benefited from debt relief initiatives - such as the 1996 Heavily Indebted Poor Countries initiative (HIPC), its 1999 enhancement, and the 2006 Multilateral Debt Relief Initiative (MDRI) — which have substantially reduced their debt burdens. These initiatives together with policy reforms have helped improve the solvency of LICs thereby providing them with additional space for new financing. For instance, countries such as Ghana in 2007 and Senegal in 2009 have tapped international debt markets to finance large infrastructure projects. Gabon, a medium-income country (MIC), also issued an international bond in 2007 to restructure its debt. In addition, African countries are increasingly relying on non-concessional debt from non-OECD creditors, including Brazil, India, and China.

Post debt relief, an important policy question is whether LICs should use this new "space" to borrow externally. More generally, the same question can be asked for countries considering accessing international capital markets for the first time.

So far, the literature has studied the "pull" and "push" determinants of capital inflows from more developed countries to LICs and MICs and stressed the associated policy challenges. For instance, Montiel (2003) notes the importance of (i) making sure that funds from external borrowing are allocated correctly within the domestic economy, (ii) avoiding macroeconomic overheating and the destabilization associated with large inflows, and (iii) mitigating the vulnerability associated with sudden capital outflows and financial crises.

However, a practical but important question that LICs face, when weighing the option to access international capital markets for the first time, is the estimation of the cost and risk of new debt, or more generally the development of a sovereign debt management strategy. In this paper, the question at hand is the likely cost of borrowing in international capital markets, as measured by the sovereign bond yield spread or interest rate.

To answer this question, we take the perspective of a country which has been able to remove its credit constraints - for instance through debt relief and policy reforms - and access capital markets for the first time. We consider that the country may not have a sovereign credit rating and has no outstanding international bonds. We also assume that both "pull" and "push" factors are the main determinants of capital inflows to the country and its cost of borrowing.

This paper presents a simple two-step approach to estimate bond yield spreads for countries which have not yet issued international bonds. First, we use an ordered probit model with macroeconomic variables as independent variables to estimate sovereign credit ratings. 
Second, we estimate the relationship between secondary markets' sovereign bond spreads and "push" and "pull" factors. Using this relationship, we then estimate a country's bond spreads using its current or estimated credit rating as a proxy for its "pull" factors. Once an estimate is obtained for the foreign currency denominated sovereign yield spread, it is possible to approximate local currency yield curves by assuming the Fisher effect or uncovered interest parity.

The methodology can be used by policymakers and debt managers in LICs to develop a sovereign debt strategy and assess the cost and risk of accessing international capital markets or borrowing at non-concessional terms. In particular, the methodology can be used to: (i) estimate LICs likely sovereign credit rating should they decide to obtain one; (ii) calculate the likely bond yield spreads or interest rate cost of their debut issuance should they consider accessing international bond markets; (iii) monitor secondary market bond yield spreads for those countries with bonds outstanding; and, finally (iv) build a foreign and local currencydenominated sovereign yield curves, which are essential outputs for sovereign as well as corporate debt managers.

The rest of the paper is organized as follows: Section II lays out the general theoretical framework followed in the paper using simple "pull" and "push" models of capital markets inflows. Section III describes the model specification used for sovereign credit rating estimates, and presents the data and the estimated results. Section IV presents the model used for estimating the cost of borrowing. Section V estimates sovereign credit ratings and bond yield spreads for a sample of Sub-Saharan African countries (SSA). Section VI illustrates the use of the model to construct sovereign foreign and local currency denominated yield curves, and Section VI concludes. 


\section{Simple "Pull" AND "Push" Models OF CAPITAl Markets Inflows}

Both the macroeconomic and the finance literature find that capital inflows from mature to LICs are a function of "pull" factors that originate in the borrowing countries, "push" factors which come from lending countries, and changes in the degree of financial integration. We choose the following two simple models for their clarity and simplicity in separating "push" and "pull" factors.

\section{A. A Simple Macro Model of "Push" and "Pull" Factors}

Following Montiel (2003), an economy's domestic return factor can be compared with the world cost of funds for the country. The equilibrium return, $R^{*}$, and value of capital inflows, $C^{*}$, are therefore determined - in addition to the degree of financial integration - by the "demand price" (LHS of Equation (1)) and the "supply price" of capital inflows (RHS of Equation (1)) which equate the domestic return factor - the product of the cost of a "project" component $D$ with a "country" component $C$-with the world cost of funds for the country, $W$, and a wedge factor $w$ :

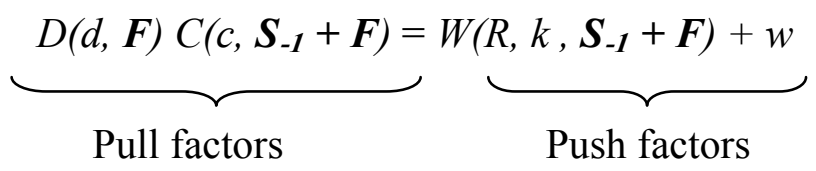

Where $D(d, \boldsymbol{F})$, the "project" component depends on the cost (marginal return) of the project, $d$, and $\boldsymbol{F}$, the flow of new debt. $C$, the "country" component, depends on the ability to repay $c$, the stock of existing debt $\boldsymbol{S}_{-1}$, and the flow of new debt $\boldsymbol{F}$. Finally, the ability to repay c is such that $c=\mathrm{Y} /(R-g)$, where $Y$ is real GDP, $\mathrm{g}$ its growth rate, and $R$ the world risk free rate.

$W\left(R, k, \boldsymbol{S}_{-\boldsymbol{1}}+\boldsymbol{F}\right)$, the world cost of fund, depends on $R$, the world risk free rate, and $k$, exogenous factors. Finally, the "supply price" of capital inflows depends on $w$, a wedge factor which could include transaction costs or Pigovian taxes. In this set-up the LHS of Equation (1) represents "pull" factors, while the RHS of Equation (1) represents "push" factors.

In this model, credit rationing is possible. However, credit rationed countries - such as most LICs - can access international capital markets through policy reforms. Such reforms would increase the marginal return of the project, $d$, or GDP growth thereby removing the credit constraint and making capital flows responsive to changes in "push" factors, such as world interest rates. 
Macroeconomic models are useful in understanding the key drivers of capital markets inflows. In contrast, finance models offer some insights on the risk-return tradeoffs faced by capital markets' investors. The next section presents a finance model which we use to inform our specification for the estimation of bond yield spreads.

\section{B. A Simple Finance Model of "Push" and "Pull" Factors}

The finance literature also relies on models of "push" and "pull" factors to estimate the cost of international capital. For instance, Rozada and Levy Yeyati (2008) use a simple reduced form model, where interest rate arbitrage by risk-averse investors implies that:

$$
(1-q)(1+r)+q V=\left(1+r_{f}\right)+\varphi q
$$

Where $q$ is the probability of default, $V$ the recovery value of the bond after default, $r$ and $r_{f}$, are the interest rates charged to the bond and to a risk-free asset of similar duration, and $\varphi$ is a parameter that reflects investors' risk aversion. One can express the sovereign borrower's spread defined as the difference between $r$ and $r_{f}$, as :

$$
\text { Spread }_{i t}=\underbrace{\theta\left(q\left(X_{i t}\right)\right.}_{\text {Pull factors }} \underbrace{\rho\left(r_{f t}, \varphi\right) \psi_{i}\left(r_{f t}\right.}_{\text {Push factors }}, d_{t})
$$

Where the sovereign spread depends on pull factors such as $\theta$, which measures the incidence of the default risk of the issuer, which depends on the probability of default, $q$ a function of country-specific fundamentals $X_{i t}$. In contrast, push factors include, $\rho$, the price of credit risk, which depends on the international risk free rate, $r_{f t}$ as well as investors' risk aversion $\varphi$ and $\psi$, a scale factor reflecting global factors that affect emerging market or LIC sovereign debt differently, such as global liquidity, proxied by $r_{f t}$ or episodes of global financial distress, $d_{t}$.

In the rest of the paper, we take the perspective of a country which has been able to remove its credit constraints - for instance through policy reforms - and access capital markets for the first time. The country may or may not have a sovereign credit rating and has no outstanding international bonds. The question at hand is the likely cost of borrowing in international markets, as measured by the sovereign bond yield spreads.

To answer this question, we use a two-step approach: first, we use the relationship between sovereign credit ratings and macroeconomic variables to proxy for "pull" factors; second, we exploit the relationship between the estimated sovereign credit ratings, indicators of "push" 
factors, and sovereign bond yield spreads to estimate the cost of external sovereign borrowing.

\section{Using Sovereign Credit Ratings to Proxy fOR "Pull" Factors}

Sovereign credit ratings convey analysts' views on a country's relative credit quality. However, empirical studies find that sovereign credit ratings are generally consistent with country-specific macroeconomic fundamentals. Early studies by Lee (1993) and Cantor and Packer (1996) find that a reduced number of macroeconomic variables explain sovereign ratings, respectively measured by Institutional Investor ratings and assigned by Moody's and S\&P's. Follow-up empirical studies confirm the findings that credit ratings can be proxied by a small number of macroeconomic variables. ${ }^{2}$ More recently, Mora (2006) uses results by Ferri, Liu, and Stiglitz (1999) as a benchmark and discusses different estimation of methods while Ratha, De, and Mohapatra (2007) provide "shadow" credit ratings for a large sample of unrated countries.

We update these models for 2000-2009 to obtain estimates of sovereign credit ratings for countries whose external debt has not been rated. When a country has outstanding ratings, we use actual ratings. However, in practice, our estimation can be used to update ratings using the latest data available for explanatory variables or their estimated value. It can also be used by an analyst to compare its own assessment of a country's ability to repay its debt with the credit rating agencies' opinion.

\section{Model Specification}

We convert credit ratings letter grades into numbers, using a scale from 1 for the highest ratings to 22 for the lowest ratings (Table 1). We then estimate the following relationship using an unbalanced panel:

$$
\begin{aligned}
& \text { Rating }_{i, t}=\alpha+\beta_{1} \text { PPPGDP }_{i, t}+\beta_{2} \text { Growth }_{i, t}+\beta_{3} \text { Inflation }_{i, t}+\beta_{4} \text { Deficit }_{i, t}+ \\
& \beta_{5} \text { CA }_{i, t}+\beta_{6} \text { DEBTEXP }_{i, t}+\beta_{7} \text { Cttype }_{i, t}+\varepsilon_{i, t}
\end{aligned}
$$

\footnotetext{
${ }^{2}$ They include Reinhart, Rogoff, and Savastano (2003) who highlight the importance of past defaults, Rowland and Torres (2004), Rowland (2005), and Sutton (2005).
} 
where subscripts $i$ an $t$ refer to country $i$ at time $t$. Rating is the sovereign credit rating assigned by Fitch, Moody, S\&P's or an average of the three ratings; PPPGDP is the purchasing power parity domestic product per capita; Growth is the growth rate of GDP; Inflation is the average annual inflation rate; Deficit is the overall budget deficit over GDP; $C A$ the current account deficit over GDP; DEBTEXP is the ratio of exports to debt; Cttype is a country dummy indicating whether a country is an industrialized country according to IMF definition, and $\varepsilon$ is the error term.

We estimate equation (4) using an ordered probit model to account for the ordinal nature of the dependent variable. ${ }^{3}$ Indeed, a linear model would treat the difference between two high grades, say an $A a a$ and a $B B$ rating, as the same as that between two lower grades, say a Baa2 and a $B a 1$. The ordered probit model appears to be a reasonable choice as it is a nonlinear regression specifically designed for a setting whereby there are multiple outcomes (alternatives of belonging to many groups). ${ }^{4} \mathrm{We}$, however, estimate a linear specification as in a number of previous studies and find consistent results.

\section{Data Description}

We use sovereign credit ratings of long-term foreign currency denominated debt from the three major agencies, Moody's, Standard \& Poor's, and Fitch. The data cover 120 countries, comprising 30 developed and 90 developing countries from 2000 to 2009 . The data show that ratings for many developing countries were only assigned during the 1990s. There were 35 countries in the sample rated in 1989, compared to 107 by 1999 and 110 by 2009.

We also use a rich dataset of macroeconomic data mostly obtained from the International Monetary Fund's IFS database, and the IMF Public Information Notice reports. We use a number of macroeconomic variables, including PPP GDP per capita, real GDP growth, CPI inflation, overall budget deficit in percent of GDP, current account balance in percent of GDP, and the external debt to exports of goods and services. We also use indicators of economic development and the history of sovereign defaults. In particular, we use a dummy

\footnotetext{
${ }^{3}$ See Hu, Kiesel, and Perraudin (2002) and Mora (2006).

${ }^{4}$ The nonlinear formulation uses an implicit function to calculate a cut value and based on this cut value to compute the probability of the cut value falling between the rating categories. In addition, the probit coefficients are estimated using the maximum likelihood method, which produces efficient estimators in a wide variety of applications, including regressions with an ordinary dependent variable. The maximum likelihood estimator is consistent and normally distributed in large sample.
} 
for whether a country is an industrial country, as classified in the World Economic Outlook of the IMF.

Table 1. Sovereign Rating Scale

\begin{tabular}{rrrr}
\hline Score & S\&P & Fitch & Moody's \\
\hline 1 & AAA & AAA & Aaa \\
2 & AA+ & AA+ & Aa1 \\
3 & AA & AA & Aa2 \\
4 & AA- & AA- & Aa3 \\
5 & A+ & A+ & A1 \\
6 & A & A & A2 \\
7 & A- & A- & A3 \\
8 & BBB+ & BBB+ & Baa1 \\
9 & BBB & BBB & Baa2 \\
10 & BBB- & BBB- & Baa3 \\
11 & BB+ & BB+ & Ba1 \\
12 & BB & BB & Ba2 \\
13 & BB- & BB- & Ba3 \\
14 & B+ & B+ & B1 \\
15 & B & B & B2 \\
16 & B- & B- & B3 \\
17 & CCC+ & CCC+ & Caa1 \\
18 & CCC & CCC & Caa2 \\
19 & CCC- & CCC- & Caa3 \\
20 & CC & CC & Ca \\
21 & C & C & C \\
22 & SD & RD & \\
& & &
\end{tabular}

Sources: Standard and Poor's, Fitch, and Moody's

\section{Estimation Results and Interpretations}

Our results are consistent with the previous literature as we find that the following macroeconomic variables: GDP per capita, inflation, overall balance to GDP, and current account balance to GDP and external debt to exports explain sovereign credit ratings (Table 2). In contrast, the real GDP growth is not significant ${ }^{5}$. Overall, external sustainability

\footnotetext{
${ }^{5}$ see for instance Mora (2006)).
} 
(current account balance) and macroeconomic stability (inflation) drive sovereign credit ratings. As inflation is highly correlated to overall budget balance, it is understandable that while inflation is highly significant (1 percent level), overall budget balance is weakly significant as its effect seems to be captured through inflation.

\section{Table 2. Estimation Results}

Ordered Probit Regression using Fitch, Moody's, S\&P, and their average rating, as dependent variable $(T=2000-2008, N=120)$

\begin{tabular}{|c|c|c|c|c|}
\hline VARIABLES & Fitch & Moody's & S\&P & AverageRating \\
\hline \multicolumn{5}{|l|}{ Regressors } \\
\hline GDP per capita & $\begin{array}{r}-0.788^{* * *} \\
(0.0574)\end{array}$ & $\begin{array}{r}-0.783^{* * *} \\
(0.0676)\end{array}$ & $\begin{array}{r}-0.814^{* * *} \\
(0.0636)\end{array}$ & $\begin{array}{r}-0.754^{* * *} \\
(0.0541)\end{array}$ \\
\hline GDP growth rate & $\begin{array}{r}0.0171 \\
(0.0139)\end{array}$ & $\begin{array}{r}0.0247^{*} \\
(0.0146)\end{array}$ & $\begin{array}{r}0.0103 \\
(0.0160)\end{array}$ & $\begin{array}{r}0.0102 \\
(0.0132)\end{array}$ \\
\hline Inflation rate & $\begin{array}{l}0.0510^{* * *} \\
(0.00721)\end{array}$ & $\begin{array}{l}0.0479^{* * *} \\
(0.00645)\end{array}$ & $\begin{array}{l}0.0459^{* * *} \\
(0.00587)\end{array}$ & $\begin{array}{l}0.0479^{* * *} \\
(0.00565)\end{array}$ \\
\hline Overall budget balance, \% GDP & $\begin{array}{r}0.000556 \\
(0.000388)\end{array}$ & $\begin{array}{r}-0.000654 \\
(0.00113)\end{array}$ & $\begin{array}{r}0.000569 \\
(0.000415)\end{array}$ & $\begin{array}{r}0.000747^{*} \\
(0.000382)\end{array}$ \\
\hline Current account balance, \% GDP & $\begin{array}{r}-0.0126^{* * *} \\
(0.00399)\end{array}$ & $\begin{array}{r}-0.00128 \\
(0.00296)\end{array}$ & $\begin{array}{r}-0.00740^{* *} \\
(0.00330)\end{array}$ & $\begin{array}{r}-0.0106^{* * *} \\
(0.00355)\end{array}$ \\
\hline External debt to exports of $g$ \& $s$ & $\begin{array}{l}0.412^{\star * *} \\
(0.0576)\end{array}$ & $\begin{array}{l}0.327^{\star \star \star} \\
(0.0683)\end{array}$ & $\begin{array}{l}0.486^{* \star *} \\
(0.0637)\end{array}$ & $\begin{array}{l}0.337^{\star \star \star} \\
(0.0544)\end{array}$ \\
\hline OECD dummy (dropped) & & & & \\
\hline $\begin{array}{l}\text { Observations } \\
\mathrm{p}\end{array}$ & $\begin{array}{r}452 \\
0\end{array}$ & $\begin{array}{r}396 \\
0\end{array}$ & $\begin{array}{r}440 \\
0\end{array}$ & $\begin{array}{r}503 \\
0\end{array}$ \\
\hline
\end{tabular}

The magnitude of our estimates is in line with Mora (2006) who used also an ordered probit model to estimate the same equation except for the GDP per capita where we a have significant difference. However our coefficient on GDP per capita has the same size as the one estimated by Ratha et al. (2007).

In the next section, we estimate the relationship between bond spreads and "pull" and "push" factors, using outstanding sovereign bonds. Since most LICs have not yet accessed international capital markets, we have to rely on emerging market bonds.

\section{Estimating Sovereign Bond Yield SPREAds USING "PuSh" AND "Pull" Factors}

As discussed earlier, sovereign bond yield spreads are determined by both "pull" and "push" factors. Credit ratings greatly influence market perceptions of a country's macroeconomic 
situation and are an important determinant of bond yield spreads, especially for first-time issuers. We therefore use them to proxy for a country's "pull" factors.

Empirical studies have shown that a number of "push" factors help explain sovereign bond yield spreads ${ }^{6}$. For instance, Sy (2002) finds that domestic indicators proxied by sovereign credit ratings and external variables which include US 10 year and 3 month interest rates, JP Morgan EMBI+ index, US high yield spreads, oil prices and crisis dummies can explain emerging market monthly sovereign spreads in 1994-2001. Hartelius, Kashiwase, and Kodres (2008) find that credit ratings, the 3-month Fed Funds future rate and its volatility, as well as the VIX index are significant in explaining spreads in 1991-2007. The CBOE volatility index (VIX) is the implied volatility of S\&P 500 stock index option prices and is a proxy investor sentiment and market volatility.

\section{Model Specification}

As discussed above, we assume that sovereign bond yield spreads are a function of "pull" and "push" factors. We therefore use Equation (2) to inform the following specification":

$$
\begin{aligned}
& \log \left(\text { spreads }_{i t}\right)=F[\text { “push” factors, "pull” factors }] \\
& \log \left(\text { spreads }_{i t}\right)=a+b X_{i t}+Z_{t}+e_{i t}
\end{aligned}
$$

\section{Data Description}

As most LICs have not yet issued sovereign bonds, we use monthly individual country bond spreads from J.P. Morgan's Emerging Markets Global Bond Index (EMBIG) from 2000 to 2009. As in step one of our approach, we use long-term sovereign credit ratings by the three major agencies to proxy for "pull" factors. In addition, we include a number of variables as "push" factors.

To measure global liquidity conditions (the so-called funding liquidity premium) we use the Fed Funds rate, the 3-month ahead Fed Funds future rate or the 3-month US T-Bill rate. All three measures are highly correlated at a monthly frequency and hence can be used as

\footnotetext{
${ }^{6}$ See Özatay, Özmen, and Şahinbeyoğlu (2007) for a review of the literature.

${ }^{7}$ We do not estimate jointly the ratings and spreads models (equations (4) and (7)) using a two-stage least square model (with a linear ratings model) because most low-income countries in our sample do not have outstanding bonds. As a result, the spreads model is estimated using emerging market countries while the ratings model relies on a much larger sample including LICs, emerging markets and developed countries.
} 
substitutes in our specification. We also include the slope of the US yield curve measured as the difference between the 10-year Treasury bond and the 3-month T-bill.

We use the VIX index as a proxy for market volatility and investor sentiment and the EMBIG composite as a measure of overall market risk. Since a number of emerging market countries are oil exporters, we also add an oil price index to our specification. For robustness checks we have also estimated our main model using the Merrill Lynch US high yield bond spreads, dummy variables for investment grade ratings, and previous crises and episodes of sovereign defaults.

We find that for the 2000-2009 period, a specification including sovereign credit ratings, the Fed fund future rate, the slope of the yield curve, the EMBIG composite, the VIX index, and oil prices explain the best individual country sovereign spreads. All the variables are significant at the one percent level.

Table 3. Estimating Emerging Market Bond Spreads 2000-2009

\begin{tabular}{|c|c|c|c|c|c|c|c|c|}
\hline \multirow[t]{2}{*}{ VARIABLES } & \multicolumn{4}{|c|}{ Fixed effects } & \multicolumn{4}{|c|}{ Random effects } \\
\hline & Avge Rating & Fitch & Moody's & S\&P & Avge Rating & Fitch & Moody's & S\&P \\
\hline \multicolumn{9}{|l|}{ Regressors } \\
\hline Rating & $\begin{array}{l}0.204 * * * \\
(0.005)\end{array}$ & $\begin{array}{l}0.161 * * * \\
(0.005)\end{array}$ & $\begin{array}{l}0.187 * * * \\
(0.006)\end{array}$ & $\begin{array}{l}0.181 * * * \\
(0.004)\end{array}$ & $\begin{array}{l}0.205 * * * \\
(0.004)\end{array}$ & $\begin{array}{l}0.165^{* * *} \\
(0.004)\end{array}$ & $\begin{array}{l}0.188 * * * \\
(0.005)\end{array}$ & $\begin{array}{l}0.183 * * * \\
(0.004)\end{array}$ \\
\hline Fed Funds rate & $\begin{array}{l}-0.027 * * * \\
(0.011)\end{array}$ & $\begin{array}{l}-0.023 * * \\
(0.012)\end{array}$ & $\begin{array}{l}-0.066 * * * \\
(0.013)\end{array}$ & $\begin{array}{l}-0.029 * * * \\
(0.010)\end{array}$ & $\begin{array}{l}-0.027 * * * \\
(0.011)\end{array}$ & $\begin{array}{l}-0.023^{* *} \\
(0.012)\end{array}$ & $\begin{array}{l}-0.065^{* * *} \\
(0.013)\end{array}$ & $\begin{array}{l}-0.029 * * * \\
(0.010)\end{array}$ \\
\hline Oil price & $\begin{array}{l}-0.142^{* * * *} \\
(0.032)\end{array}$ & $\begin{array}{l}-0.138^{* * *} \\
(0.036)\end{array}$ & $\begin{array}{l}-0.107 * * * \\
(0.037)\end{array}$ & $\begin{array}{l}-0.116^{* * *} \\
(0.031)\end{array}$ & $\begin{array}{l}-0.140^{* * * *} \\
(0.032)\end{array}$ & $\begin{array}{l}-0.133^{* * *} \\
(0.036)\end{array}$ & $\begin{array}{l}-0.106^{* * *} \\
(0.037)\end{array}$ & $\begin{array}{l}-0.114 * * * \\
(0.031)\end{array}$ \\
\hline VIX index & $\begin{array}{l}0.840 * * * \\
(0.024)\end{array}$ & $\begin{array}{l}0.781^{* * * *} \\
(0.026)\end{array}$ & $\begin{array}{l}0.761 * * * \\
(0.027)\end{array}$ & $\begin{array}{l}0.855^{* * *} \\
(0.023)\end{array}$ & $\begin{array}{l}0.845^{* * *} \\
(0.024)\end{array}$ & $\begin{array}{l}0.787 * * * \\
(0.026)\end{array}$ & $\begin{array}{l}0.765 * * * \\
(0.027)\end{array}$ & $\begin{array}{l}0.860^{* * * *} \\
(0.023)\end{array}$ \\
\hline Slope US yield curve & $\begin{array}{l}0.026 * * * \\
(0.007)\end{array}$ & $\begin{array}{l}0.025^{* * *} \\
(0.008)\end{array}$ & $\begin{array}{l}0.038^{* * *} \\
(0.009)\end{array}$ & $\begin{array}{l}0.025^{* * * *} \\
(0.007)\end{array}$ & $\begin{array}{l}0.026 * * * \\
(0.007)\end{array}$ & $\begin{array}{l}0.024 * * * \\
(0.008)\end{array}$ & $\begin{array}{l}0.038^{* * *} \\
(0.009)\end{array}$ & $\begin{array}{l}0.025 * * * \\
(0.007)\end{array}$ \\
\hline Us high yield spreads & $\begin{array}{l}-0.374 * * * \\
(1.000)\end{array}$ & $\begin{array}{l}-0.573 * * * \\
(0.112)\end{array}$ & $\begin{array}{l}-0.502 * * * \\
(0.116)\end{array}$ & $\begin{array}{l}-0.348^{* * *} \\
(0.097)\end{array}$ & $\begin{array}{l}-0.366^{* * *} \\
(1.000)\end{array}$ & $\begin{array}{l}-0.563^{* * *} \\
(0.112)\end{array}$ & $\begin{array}{l}-0.491 * * * \\
(0.116)\end{array}$ & $\begin{array}{l}-0.339 * * * \\
(0.097)\end{array}$ \\
\hline Constant & $\begin{array}{l}3.612 * * * \\
(0.574)\end{array}$ & $\begin{array}{l}5.483 * * * \\
(0.630)\end{array}$ & $\begin{array}{l}4.716^{* * *} \\
(0.657)\end{array}$ & $\begin{array}{l}3.569 * * * \\
(0.550)\end{array}$ & $\begin{array}{l}3.575 * * * \\
(0.575)\end{array}$ & $\begin{array}{l}5.398 * * * \\
(0.633)\end{array}$ & $\begin{array}{l}4.627 * * * \\
(0.658)\end{array}$ & $\begin{array}{l}3.511 * * * \\
(0.552)\end{array}$ \\
\hline Observations & 3184 & 2915 & 2879 & 3153 & 3184 & 2915 & 2879 & 3153 \\
\hline R-squared & 0.7741 & 0.726 & 0.738 & 0.762 & 0.763 & 0.728 & 0.739 & 0.763 \\
\hline
\end{tabular}

Table 3 reports fixed and random effects estimates of bond spreads and show that all coefficients are significant. A rating downgrade indicates deterioration in the macroeconomic stability and external sustainability of a given economy, and consequently an increase in spreads (a positive sign given the way we scaled ratings). As a number of emerging market economies are oil exporters, an increase in oil price typically lead to spread tightening (negative sign). Higher investor risk aversion or overall market risk as measured 
by the VIX index also leads to spreads widening (positive sign). A steeper US yield curve, which typically indicates higher US economic growth, is also associated with lower emerging market spreads (positive sign).

Our indicators of global liquidity (Fed Funds rate, the 3-month ahead Fed Funds future rate, and the 3-month US T-Bill rate) have a negative sign. The empirical evidence on the impact of international interest rates is mixed. ${ }^{8}$ Some studies such as Arora and Cerisola (2001) and Sy (2002) find a positive relationship between US interest rates and spreads. One explanation for this result is that a low funding liquidity premium is typically associated with low emerging market bond spreads as investors — in their search for yield — reallocate funds from low yielding assets in mature markets to higher yielding emerging market sovereign bonds. In contrast other studies, such as Eichengreen and Mody (2000) find a negative interest rate coefficient. They argue that lower US interest rates increase the supply of emerging market bonds, thereby raising launch spreads.

Our results can be explained by the significant changes in the relationship between emerging market bond spreads that have occurred in the 2000-2009 decade. First, "pull" factors in many emerging markets such as Brazil were improving during most of the period, reducing bond spreads. Indeed prior to the subprime crisis in the US crisis, EM sovereign spreads were decreasing as the credit quality of emerging market sovereign spreads improved during the period. For instance, the average rating of the EMBIG was investment grade as of early 2010.

Second, our results are also in part due to (i) falling long-term US and global interest rates even as the Federal Reserve raised the level of the target federal funds aggressively- the socalled "conundrum," and (ii) the global financial crisis that started in July 2007 in the US. During both episodes, US short-term interest rates were negatively associated with emerging market bond spreads. In the first case, a sustained cycle of tightening by the Fed (which started in April 2004) coincided with a narrowing of emerging market spreads. ${ }^{9}$ In the second episode, Fed easing in response to the crisis which started in July 2007 coincided with a sharp widening of emerging market bond spreads. As a result, our sample exhibit a positive correlation between US short rates and emerging market bond spreads only for a short interval starting some time in 2002 and ending prior to the Fed tightening cycle.

\footnotetext{
${ }^{8}$ See Özatay, Özmen, and Şahinbeyoğlu (2007) for a useful discussion of the literature.

${ }^{9}$ Indeed, as Greenspan (2005) indicates, “....we should be careful in endeavoring to account for the decline in long-term interest rates by adverting to technical factors in the United States alone because yields and risk spreads have narrowed globally...And spreads of yields on bonds issued by emerging-market nations over U.S. Treasury yields have declined to very low levels."
} 
As a robustness test, we use G4 M2 or reserve money for the euro area, Japan, the United Kingdom, and the United States, instead of US interest rates as an alternative measure of global liquidity. ${ }^{10}$ Our results do not change significantly, and the coefficient for global liquidity is positive, which is consistent with the negative sign of US interest rates in the previous estimation (Table 4).

Finally, our coefficient for spreads on U.S. high yield corporate bonds also has a negative sign. Previous studies often use U.S. high yield spreads as an indicator of global risk appetite for crossover investors, who invest in both the emerging market and U.S. high yield corporate bond asset classes. Such investors typically would allocate funds to higher yielding emerging market bonds when U.S. corporate bond spreads tighten, resulting in a decrease in emerging market bond spreads (a positive relationship). However, the improving quality of emerging market sovereign issuers indicates that this relationship may have become more tenuous in 2000-2009. As discussed above, EM sovereign spreads are showing a decreasing trend during this period, excluding the US subprime crisis. In contrast, U.S. high yield spreads increased over the period, showing a negative relationship with emerging market bond spreads.

Table 4. Liquidity and Emerging Market Bond Spreads 2000-2009

\begin{tabular}{lcc}
\hline Variables & Fixed Effects & Random Effects \\
\hline Regressors & Avge Rating & Avge Rating \\
Rating & $0.198^{* * *}$ & $0.199^{* * *}$ \\
& $(0.006)$ & $(0.005)$ \\
Liquidity (lagged one period) & $0.776^{* * *}$ & $0.783^{* * *}$ \\
& $(0.108)$ & $(0.108)$ \\
Oil price & $-0.08^{* * *}$ & $-0.078^{* * *}$ \\
& $(0.035)$ & $(0.035)$ \\
Vix index & $0.616^{* * *}$ & $0.619^{* * *}$ \\
& $(0.035)$ & $(0.034)$ \\
Slope US yield curve & $0.037^{* * *}$ & $0.036^{* * *}$ \\
& $(0.006)$ & $(0.006)$ \\
US high yield spreads & $-1.361^{* * *}$ & $-1.355^{* * *}$ \\
& $(0.143)$ & $(0.143)$ \\
Constant & $3.354^{* * *}$ & $3.279^{* * *}$ \\
& $(0.539)$ & $(0.539)$ \\
& & 3184 \\
Observations & 3184 & $\mathrm{R}^{2}=0.7809$ \\
\hline R-squared & $\mathrm{R}^{2}=.07805$ & \\
\hline All variables in logs & & \\
Standard errors in parentheses & & \\
$* * * p<0.01, * * p<0.05, * p<0.1$ & & \\
\hline${ }^{10}$ See IMF $(2010)$ for a discussion of global liquidity trends. & & \\
& &
\end{tabular}




\section{Estimates of Spreads for Sub-Saharan Africa}

Using the relationship between sovereign bond yield spreads and "push" and "pull" factors obtained above, we can now estimate bond spreads for a sample of Sub-Saharan African countries as of September 2009. We focus on rated countries so as to compare our estimates with actual ratings.

For the first step of our methodology, Table 5 shows actual and estimated ratings and spreads for the 19 sub-Saharan countries which are rated by at least one credit rating agency. Overall, our estimates of ratings for the 15 countries for which we have a complete set of explanatory variables are comparable with actual ratings, although for a few countries (Cameroon, Cape Verde, and Namibia), differences (both over- and under-estimations) can be up to two credit notches. The greatest differences are for South Africa (3 notches) and Gabon (4 notches). These results can be attributed to forecast errors and the fact that credit ratings are opinions based on both quantitative and qualitative analyses while our model relies exclusively on macroeconomic variables (see Bhatia, 2002).

Table 5 also shows actual and estimated sovereign spreads and interest rates for sub-Saharan Africa as of September 2009. Our estimates are comparable to actual values for the three countries with bonds outstanding and which are included in the JP Morgan EMBIG index (Ghana, Gabon, and South Africa). The average estimated interest rate for SSA countries is 9.60 percent (or a spread of 629 basis points) with values ranging from 4.35 and 4.78 percent for Botswana and South Africa, respectively to 11.43 percent for both Mali and Rwanda. The interest rate for Seychelles is at distressed level at 32.28 percent but this is not surprising as the country experienced a near exhaustion of foreign reserves and a default of its public debt in mid-2008. Excluding Seychelles, the average interest rate for SSA countries falls to 8.34 percent (or 503 basis points).

The case of Senegal is interesting as our estimates are for September 2009 while Senegal issued a sovereign bond for the first time in December 2009. Our estimates are 1.52 percent or 152 basis points higher than the actual cost paid by Senegal. Since we use secondary market spreads in our estimation, part of this difference can be attributed to the premium that issuers pay to access capital markets for the first time. Part of the premium on the Senegalese issue can also be attributed to its size as it was smaller than typical debut bond for sovereign issuers (US\$ 200 million in contrast to US\$500 million on average). By May 2010, Senegal's spreads tightened to 659 basis points or an interest rate of 9.9 percent, a bit closer to our estimate of 8.70 percent.

In general, our results suggest that as of September 2009, the average SSA hypothetical borrower would have paid 2.92 percent more than the average emerging market borrower. Indeed, the average JP Morgan EMBIG interest rate stood at 6.68 percent (or a spread of 337 basis points) during the same period. However, the four SSA countries which have already issued bonds (Gabon, Ghana, Senegal, and South Africa) paid on average 1.34 percent more 
than the average emerging market sovereign borrower, with South Africa actually paying 1.40 percent less.

In practice, countries considering access international capital markets need to consider a number of issues in addition to the cost of borrowing. Das, Papaioannou, and Polan (2008) flag key preconditions and strategic considerations that such countries need to take into account. In particular, they note that successful issuers had a clear use for the proceeds of the debut bond, which did not compromise their creditworthiness. They also examined the balance sheet implications of the issue within a medium-term macroeconomic framework. Successful issuers also had to decide about strategic considerations of a debut issue, including its size, maturity, choice or fixed versus flexible interest rate, and currency of denomination. Key tactical considerations included the choice of legal and financial advisors, underwriters, and jurisdiction of issuance.

Table 5. Actual and Estimated Sovereign Credit Ratings, Spreads, and Interest Rates

\begin{tabular}{|c|c|c|c|c|c|c|c|c|}
\hline \multirow[b]{2}{*}{ September 2009} & \multicolumn{3}{|c|}{ Actual Ratings } & \multirow[t]{2}{*}{ Estimated Ratings } & \multicolumn{2}{|c|}{ Actual Cost } & \multicolumn{2}{|c|}{ Estimated Cost } \\
\hline & $S \& P ' s$ & Fitch & Moody's & & $\begin{array}{c}\text { Spreads }{ }^{1} \\
\text { (in bps) }\end{array}$ & $\begin{array}{r}\text { Interest rate } \\
\text { (in percent) }\end{array}$ & $\begin{array}{r}\text { Spreads } \\
\text { (in bps) }\end{array}$ & $\begin{array}{l}\text { Interest rate } \\
\text { (in percent) }\end{array}$ \\
\hline Benin & B & NR & $\mathrm{B}$ & $\mathrm{B} / \mathrm{B} / \mathrm{B} 2$ & $\ldots$ & $\ldots$ & 661 & 9.92 \\
\hline Botswana & A- & NR & $\mathrm{A} 2$ & $\ldots$ & $\ldots$ & $\ldots$ & 104 & 4.35 \\
\hline Burkina Faso & B & NR & NR & $\ldots$ & $\ldots$ & $\ldots$ & 661 & 9.92 \\
\hline Cameroon & B & B & NR & BB-/BB-/Ba3 & $\ldots$ & $\ldots$ & 661 & 9.92 \\
\hline Cape Verde & NR & $\mathrm{B}+$ & NR & $\mathrm{BB} / \mathrm{BB} / \mathrm{Ba} 2$ & $\ldots$ & $\ldots$ & 539 & 8.70 \\
\hline Gabon & BB- & BB- & NR & $\mathrm{BBB} / \mathrm{BBB} / \mathrm{Baa} 2$ & 455 & 7.86 & 439 & 7.70 \\
\hline Ghana & $\mathrm{B}+$ & $\mathrm{B}+$ & NR & $\mathrm{B} / \mathrm{B} / \mathrm{B} 2$ & 542 & 8.73 & 539 & 8.70 \\
\hline Kenya & B & $\mathrm{B}+$ & NR & $\mathrm{B} / \mathrm{B} / \mathrm{B} 2$ & $\ldots$ & $\ldots$ & 597 & 9.28 \\
\hline Lesotho & NR & NR & BB- & $\mathrm{B} / \mathrm{B} / \mathrm{B} 2$ & $\ldots$ & $\ldots$ & 439 & 7.70 \\
\hline Mali & NR & NR & B- & $\mathrm{B} / \mathrm{B} / \mathrm{B} 2$ & $\ldots$ & $\ldots$ & 812 & 11.43 \\
\hline Mauritius & NR & NR & Baa2 & $\ldots$ & $\ldots$ & $\ldots$ & 193 & 5.24 \\
\hline Mozambique & $\mathrm{B}+$ & B & NR & $\mathrm{B}+/ \mathrm{B}+/ \mathrm{B} 1$ & $\ldots$ & $\ldots$ & 597 & 9.28 \\
\hline Namibia & NR & BBB- & NR & $\mathrm{BB} / \mathrm{BB} / \mathrm{Ba} 2$ & $\ldots$ & $\ldots$ & 237 & 5.68 \\
\hline Nigeria & $\mathrm{B}+$ & BB- & NR & $\mathrm{B}+/ \mathrm{B}+/ \mathrm{B} 1$ & $\ldots$ & $\ldots$ & 486 & 8.17 \\
\hline Rwanda & NR & B- & NR & B-/B-/B3 & $\ldots$ & $\ldots$ & 812 & 11.43 \\
\hline Senegal & $\mathrm{B}+$ & NR & NR & $\mathrm{B}+/ \mathrm{B}+/ \mathrm{B} 1$ & $691^{2}$ & 10.22 & 539 & 8.70 \\
\hline Seychelles & NR & NR & B- & $\ldots$ & $\ldots$ & $\ldots$ & $2896^{3}$ & 32.28 \\
\hline South Africa & $\mathrm{BBB}+$ & $\mathrm{BBB}+$ & A3 & $\mathrm{BB}+/ \mathrm{BB}+/ \mathrm{Ba} 1$ & 197 & 5.28 & 147 & 4.78 \\
\hline Uganda & $\mathrm{B}+$ & B & NR & B-/B-/B3 & $\ldots$ & $\ldots$ & 597 & 9.28 \\
\hline SSA average & & & & & & & 629 & 9.60 \\
\hline EM average & & & & & & & 337 & 6.68 \\
\hline
\end{tabular}

The proposed approach can also be used to proxy for sovereign and corporate yield curves as explained below. 


\section{Constructing Sovereign ANd Corporate Yield CuRves}

For a country with no or underdeveloped capital markets, estimates of sovereign bond yield spreads can be used to construct sovereign yield curves in foreign and domestic currencies. Such yield curves could be used by debt managers to assess the benefits and risks of different sovereign borrowing strategies. Sovereign yield curves can also be used by corporate to estimate their cost of debt capital. These estimations depend of course on a number of assumptions such as the Fisher effect or uncovered interest parity (UIP) but in the context of LICs with shallow capital markets, the resulting yield curves can be used by policy makers, debt managers, and corporates to estimate the cost and risk of different financing scenarios when considering accessing capital markets.

\section{US dollar Sovereign Yield Curve (spot and forward)}

From the model above (Equation (7)), one can obtain an estimate of the LIC's US dollar sovereign bond spread, $s_{t}$. Assuming parallel yield curves, the sovereign US dollar denominated sovereign spot yield curve can be approximated by adding the bond spread, $s_{t}$ to the US yield curve ${ }^{11}$ :

$$
i_{D o m, \$, t}^{m}=i_{U S, t}^{m}+s_{t}
$$

where $i_{U S, t}^{m}$ is the average par yield on US Treasury bonds with maturity $m$ at time $t$ and $i_{D o m, \$, t}^{m}$ the average par yield on dollar denominated bonds with a similar maturity issued by the LICs.

Approximations of the US dollar and local currency denominated forward curves can be obtained by using the forward US Treasury yield curve rather than the spot curve.

\section{Euro or Yen Sovereign Yield Curve}

The country's Euro or Yen denominated sovereign yield curve can also be approximated by adding the cost of a Euro/US\$ (or Yen/ $\$$ swap), $\delta$, to the country's US dollar denominated yield curve.

$$
i_{D o m, \in, t}^{m}=i_{U S, t}^{m}+s_{t}+\delta_{\in, t}
$$

\footnotetext{
${ }^{11} \mathrm{US}$ yield curve data are available from $\mathrm{http}: / / \mathrm{www}$.ustreas.gov/offices/domestic-finance/debtmanagement/interest-rate/yield.shtml
} 


\section{Local Currency Domestic Government Yield Curve (no active forward markets)}

For countries with no active forward and swap markets, the local currency (domestic) government yield curve can be approximated from the US dollar curve using the inflation differential between the LIC and the US (Fisher effect):

$$
i_{D o m, L C, t}^{m}=i_{D o m, \$, t}^{m}+\pi_{D o m, t}-\pi_{U S, t}
$$

Where $\pi_{\mathrm{Dom}, \mathrm{t}}$ and $\pi_{\mathrm{US}, \mathrm{t}}$ denote the domestic and US inflation rates, respectively and $i_{D o m, \$, t}^{m}=i_{U S, t}^{m}+s_{t}$ as above.

\section{Local Currency Domestic Government Yield Curve (active forward markets)}

When active forward and swap markets exist, the local currency (domestic) government yield curve can be approximated using covered interest rate parity (UIP):

$$
i_{D o m, L C, t}^{m}=i_{D o m, \$, t}^{m}+f_{D o m, t}^{m}-s_{t}
$$

Where $f$ and $s$ denote the t-periods ahead forward exchange rate and the sport rate, respectively. Both rates are measured in units of local currency per foreign currency.

\section{Corporate Yield Curves}

In countries with no or shallow capital markets, the sovereign benchmarks obtained above can be useful to estimate the cost of corporate debt capital. Indeed, an estimate of the corporate credit spread can be added to the sovereign benchmark to proxy for the corporate yield curve.

The framework developed in this paper also gives corporate some guidance on the interrelations between "push" and "pull" factors on their cost of capital. 


\section{Conclusions}

The question of the cost of accessing international capital markets has become increasingly important in countries, such as low income countries (LICs) where debt relief and improved macroeconomic policy have created significant borrowing space. Even for countries under IMF programs, the policy of prohibiting non-concessional debt has been made more flexible and takes into account both a country's institutional capacity and its debt sustainability.

Some countries such as Ghana and Gabon (a medium income country, MIC) in 2007 and Senegal in 2009 have already tapped international capital markets for the first time and others are scheduled to follow suit. Others are considering borrowing at non-concessional terms, at times from new creditor countries such as Brazil, China, and India. For such countries, this paper provides a method to estimate their likely credit rating and cost of borrowing in international capital markets, as measured by the sovereign bond yield spreads. Our estimates indicate that the average SSA country would have paid about 3 percent more than the average emerging market borrower or 9.60 percent as of end-2009. The proposed method can also help these countries benchmark the cost of capital markets borrowing with other sources of non-concessional financing, including bilateral loans.

The question of whether a low income or medium income country should access international capital markets for the first time should, of course, not be viewed solely from a cost angle. The macroeconomic literature has insisted on making sure that when countries access international capital markets, funds are allocated correctly within the domestic economy, and that policies avoid destabilization associated with large inflows and outflows, in particular those associated with financial crises.

In addition, improving debt management institutional capacity in LICs sovereign should be a priority for policy makers. The decision to access international capital markets should then be the result of an appropriate debt management strategy which determines the appropriate composition of sovereign debt and ensures that the level and terms of borrowing can be sustained. The methodology developed in the paper can help assess the cost and risk of such a strategy for countries accessing international debt markets for the first time. 


\section{REFERENCES}

Bathia, Ashok, 2002. "Sovereign Credit Rating Methodology: An Evaluation”, IMF Working Paper, IMF/WP/02/170.

Cantor, Richard Martin and Packer, Frank, "Sovereign Credit Ratings," in Current Issues in Economics and Finance, Vol. 1, No. 3, June 1995.

Das Udaibir S., M. Papaioannou, and M. Polan, 2008, "Strategic Considerations for FirstTime Sovereign Bond Issuers,” IMF Working Paper, IMF/WP/08/261

Eichengreen, Barry, and Ashoka Mody. 2000. "What Explains Spreads of Emerging Market Debt?" in Capital Flows and the Emerging Economies: Theory, Evidence, and Controversies, Ed. By Sebastian Edwards (Chicago and London: University of Chicago Press), pp. 107-34.

Ferri, Giovanni, Li-Gang Liu and Joseph Stiglitz, 1999. "Are Credit Ratings Pro-cyclical? Evidence from East Asian Countries.”Economic Notes 28(3): 335-355.

Ferri, G., Liu, L., Majnoni, G., 2001. « The Role of Ratings Agencies Assessments in Less Developed Countries: Impact of the Proposed Basel Guidelines" Journal of Banking and Finance 25, 115-148.

Gonzàlez-Rozada, M., and E. Levy Yeyati, "Global Factors and Emerging Market Spreads", The Economic Journal, 118, November, pp. 1917-1936.

Hartelius, Kristian, K. Kashiwase, and L. Kodres, 2008 "Emerging Market Spread Compression: Is it Real or is it Liquidity?" IMF Working Paper, WP/08/10.

IMF, 2010, "Global Liquidity Expansion: Effects on Receiving Economies and Policy Response Options," in Global Financial Stability Report, Chapter 4, April, Washington DC

Lee, Suk Hun, 1993. "Are the Credit Ratings Assigned by Bankers Based on the Willingness of LDC Borrowers to Repay?” Journal of Development Economics 40: 349-59.

Montiel, Peter, 2003. "Macroeconomics in Emerging Markets" Cambridge University Press. 
Mora, Nada. 2006. "Sovereign Credit Ratings: Guilty Beyond Reasonable Doubt?” Journal of Banking \& Finance 30: 2041-2062.

Özatay F., E. Özmen, and G. Şahinbeyoğlu, 2007, "Emerging Market Sovereign Spreads, Global Financial Conditions and U.S. Macroeconomic News," ERC Working Papers in Economics, December

Ratha, Dilip, Prabal De and Sanket Mohapatra. 2007. Shadow Sovereign Ratings for Unrated Developing Countries, World Bank Policy Research Working Paper No. 4269.

Reinhart, Carmen M., Kenneth S. Rogoff and Miguel A. Savastano. 2003. "Debt Intolerance" Brookings Papers on Economic Activity 1: 1-74.

Rowland, Peter and Jose L. Torres. 2004. "Determinants of Spread and Creditworthiness for Emerging Market Sovereign Debt: A Panel Data Study."Mimeo. Banco de la República, Bogota.

Rowland, Peter. 2005. "Determinants of Spread, Credit Ratings and Creditworthiness for Emerging Market Sovereign Debt: A Follow-Up Study Using Pooled Data Analysis.”

Sutton, Gregory, 2005, "Potentially Endogenous Borrowing and Developing Country Sovereign Credit Ratings," Financial Stability Institute Occasional Paper 5. Bank for International Settlements Basel.

Sy, Amadou N. R., 2002, "Emerging Market Bond Spreads and Sovereign Credit Ratings:Reconciling Market Views with Economic Fundamentals," Emerging Markets Review, 380-408 